\title{
An ultrasound device for bacterial elimination in the mouth of patients with cleft palate: design and prototype construction
}

\author{
Ricardo Mastachi Torres ${ }^{1}$ \\ ${ }^{1}$ Universidad Iberoamericana de Puebla, México, ricardo.mastachi@anxech.com
}

\begin{abstract}
The cleft palate is a congenital malformation that is highly susceptible to infections. Physicians use different methods trying to kill the mouth bacteria, but most of them are highly invasive or painful for the young patients. Therefore, with the aim to decrease the infection risk in cleft palate patients, this work proposes the prototype design of an ultrasound emitting device embedded in a palatal obturator. The ultrasound emitting device was designed using CAD software and open-source circuits, and the prototype was developed using PLA, photopolymer resin and low-density polyurethane.
\end{abstract}

Keywords-Ultrasound, Bacterial elimination, Cleft palate, Palatal obturator.

\section{INTRODUCTION}

Cleft palate is a craniofacial condition in which the roof of the mouth contains an opening into the nose, and is one of the most common congenital malformations. In 2003, 9.6 new cases were reported daily around the world, which represented between 0.8 and 1.6 new incidences for every 1000 births [1]. Particularly, it is the most common craniofacial anomaly in México, where between 2003 and 2009 a mean of 1,510 annual cases were reported [2].

These patients suffer from oral infections that, among other consequences, cause hearing loss in the long term [3] implying complications in the speech, which impact the self-stem of the patients. The responsible infection of hearing loss is otitis media with effusion, that is present in $97 \%$ of patients with cleft palate [4]. Thus, the necessity to prevent bacterial infections that can cause audition loss in the patients' early years.

A potential solution to kill bacteria is the use of ultrasound (US), which is already used in the industry as a sterilization instrument [5], even though in medicine it is mainly employed for different purposes, such as therapy or exploration [6].

Some advantages of using ultrasound are that it does not harm human cells, the tissue can be exposed to it several times and it is non-intrusive, even when applied at higher frequencies and intensities, needed to kill bacteria [7].

In general, the US is functional due to cavitation. Cavitation refers to the formation of vapor bubbles that explode instantly, and in an infected area, it produces the bacterial inactivation. Vapor is generated due to the expansion that sound waves produces, creating low-pressure temporal zones that the liquid medium evaporates. This continuous process creates shearing forces in the bacteria that breaks its cellular wall [16]. It is also useful in cleaning bacteria biofilms that tend to accumulate in the mouth [17].

Therefore, this work proposes the development of a prototype that permits the emission of ultrasound in the mouth of infant patients with cleft palate, to eliminate bacteria.

The following sections explain in detail the design and developing processes. Section II discusses the requirements of the device, and Section III explores the prototype design process, including the materials selection and construction, with our preliminary results in Section IV. Finally, in Section $\mathrm{V}$ the conclusions are exposed.

\section{REQUIREMENTS ANALYSIS}

\section{A. Requirements}

Our goal is to develop a mechanism that could eliminate bacteria in the mouth of pediatric patients, whose ages range between zero and eight months old. Such device should not harm the mouth of the infants and must be able to be adapted to a prosthesis such as the palatal obturator, currently used as a presurgical treatment [8].

The size of the mouth of the patients is decisive for the kind of technology selected, as it limited the size and shape of the prototype. Due to its characteristics, the most used method to obtain a model of the palate of a baby is by making an impression on silicone, from which the palatal obturator is constructed in acrylic [9]. As pediatric odontology professionals produce the palatal obturators manually, it is possible to embed a device such as a piezoelectric into the prosthesis.

In industry, there are two options widely used to kill bacteria. One of them is the ultraviolet light [10] and the other, ultrasound [11]. However, ultraviolet light damages DNA inside human cells after some exposure, and it raises the chances for the patient to develop cancer [12]. 
Table 1. Related work on US effect on bacteria for bacterial and biofilm elimination.

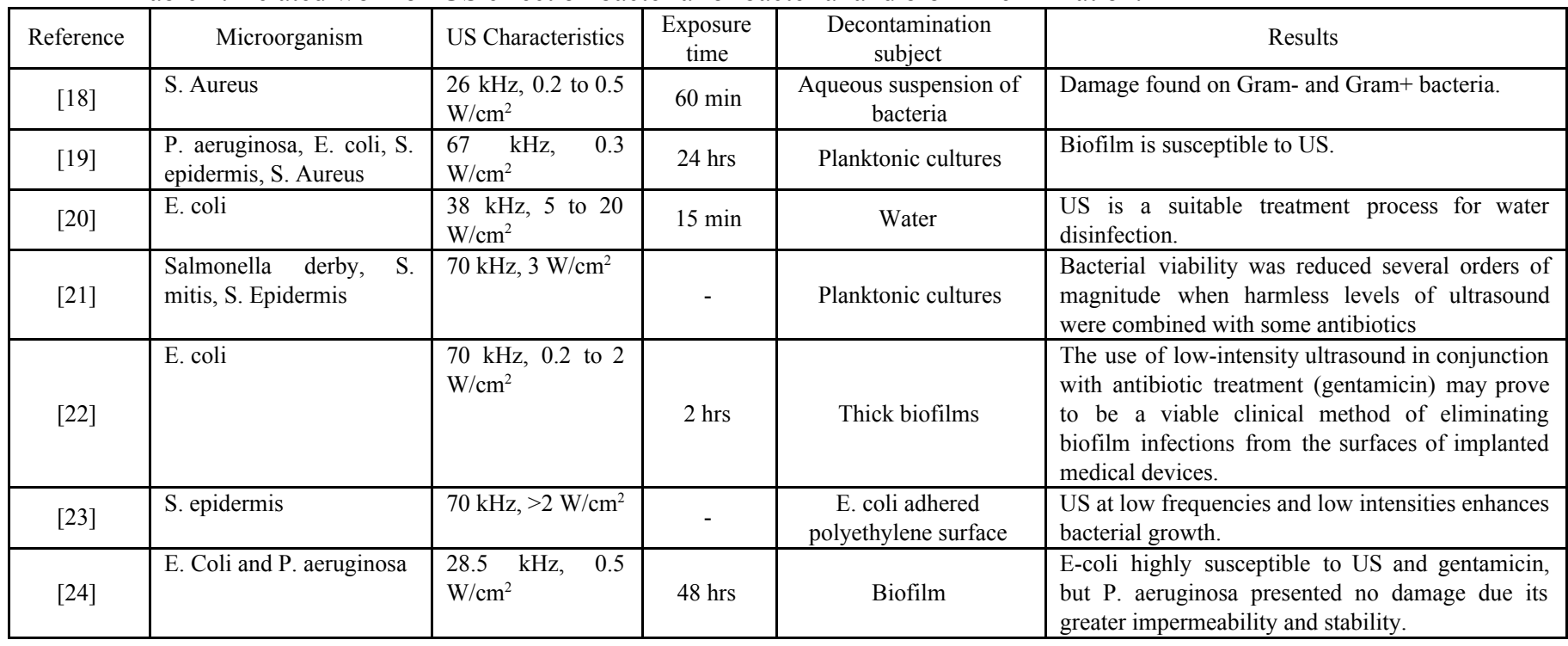

On the other hand, a widely used surface cleaning method consists in exposing the contaminated surface to ultrasound in a liquid medium. Controlled ultrasound does not harm to the human cells [7]; moreover, it has the property to boost some biological processes, such as physical recovery [13] and has specific adjustable characteristics to benefit the human body [14]. A study advices that the risk of an adverse biological response from a postnatal patient to the US is minimal, using nonthermal processes [15]. Hence, the use of an ultrasound emitter embedded in a palatal obturator made of acrylic is a potentially viable solution.

\section{B. Bacteria Inactivation}

The US cleaning method has been tested in laboratory experiments with bacteria cultures and bacterial biofilms [5].

Table 1 presents several studies regarding the effects of US on bacteria.

An application of the proposed device is to combat the risk of infections that lead to hearing loss caused by otitis. Thus, our goal is to inactivate bacterias related to otitis media with effusion in patients with cleft palate [25]-[27]. The works of [28], [29] and [30], mention Streptococcus

e an HC SR04 rangefinder ultrasonic transducer, which contains both an emitter and a receptor piezoelectric. These sensor works at $40 \mathrm{kHz}$ and emits $110 \mathrm{~dB}$, a frequency that has shown to be able to kill bacteria without harming other kinds of tissue [5]. They are $11 \mathrm{~mm}$ in diameter, making it possible to integrate the device into a palatal obturator. pneumoniae and Haemophilus influenzae as the most common bacteria involved in otitis.

The amount of power required in the US to damage bacteria with cavitation, among other variables, is the singular bacteria's diameter [31]. This allows the system to kill bacteria while leaving human cells safe. Streptococcus pneumoniae has a diameter between 0.5 and 1.25 micrometers [32]. Blood red cells are the smaller human cells in volume and can be at least six times bigger than these bacteria [33].

A secondary effect of the US in bacteria that can aid in the patient's treatment is the ability of ultrasound to make bacteria more susceptible to antibiotics [34]. Therefore, another application for the US device developed in this work is the prevention of infections after the palatal surgery, because they can put at risk the life of the patient [35].

Moreover, patients with upper respiratory tract infections had the worst development after reconstructive palatal surgery due to fistula formation [36]. The most common bacteria that cause infections in those patients is Staphylococcus aureus [37], Streptococcus mitis, Streptococcus sanguinis and Streptococcus salivarius [38].

\section{Prototype design AND COnStruction}

In the proposed prototype we us

The receptor transducer was used in a secondary system, which ensured the correct function of the apparatus by sensing ultrasound at the specified frequency. A square signal generator controls the transducer, which was produced using a microcontroller with the Open Source platform Arduino and a power phase, using a BJT transistor. A waterproof case contains the transducer, allowing the sensor to be placed in the

$1^{\text {th }}$ LACCEI International Multi-Conference for Engineering, Education, and Technology: "Innovation in Education and 
palatal obturator, reducing the ultrasound emission minimally. For its correct function, the palatal obturator had to be rigidly bonded to one face of the piezoelectric, so that it would serve as a support body for its movement, while, at the same time, the other face had to be exposed to the tissue in the palate. To avoid liquids, and thus electrical failures, a membrane was placed in the middle.

We evaluate various prototypes in the process. The first one was created to test if it was possible to attach the piezoelectric device to the palatal obturator (already used as a presurgical treatment), which is made of acrylic and goes through a hardening process during its molding [9]. So, in this stage of the construction, the piezoelectric was placed directly on the acrylic and then covered with a membrane of low-density polyurethane, to hold it together with the palatal obturator. This one did not work because the acrylic did not make an adhesive bond with any of the materials.

The second and third prototypes were made in parallel, to test two different ideas: one of them consisted of a capsule that would be placed in the palatal obturator with adhesive and the second one was built thermoforming two layers of acetate, a thick one and a thin one, surrounding the transducer, so that the latter could use the thick one as support body and the thin one, as a protection membrane. The capsule was designed in $\mathrm{CAD}$, being $15 \mathrm{~mm}$ in diameter, and produced by additive manufacturing (3D Printing); the membrane was placed using silicone adhesive.

\section{Preliminary Results AND discussion}

For waterproofness assessment, we submerged the prototypes in water for 10 minutes (Fig. 1). Only the capsule-type prototype was impermeable. Thus our third prototype is based on capsule-type design.

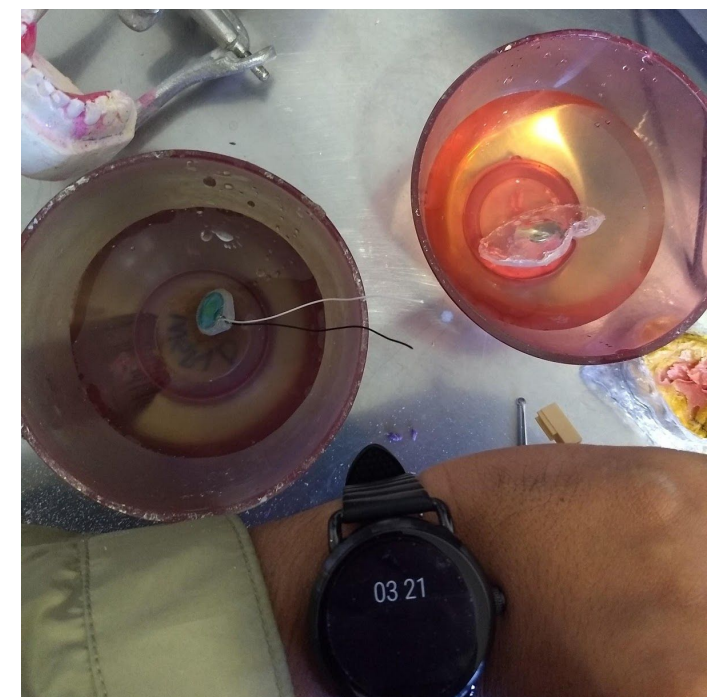

Fig. 1 Second and third prototypes in water.
The diameter of the third prototype is $12 \mathrm{~mm}$; we added a duct for the cables to make it more hermetic, as seen in Fig. 2. The capsule was made in the Formlabs Form 2 stereolithography machine, chosen for its high precision and because it has special resins for dental devices. The result is shown in Fig. 3. The material used to build the capsule was a photopolymer resin, while the protection membrane was made using a low-density polypropylene sheet. Finally, the membrane was pasted to the palatal obturator with oral prosthesis adhesive. It is important to highlight that the entire digital manufacturing of the capsule uses food-grade materials.

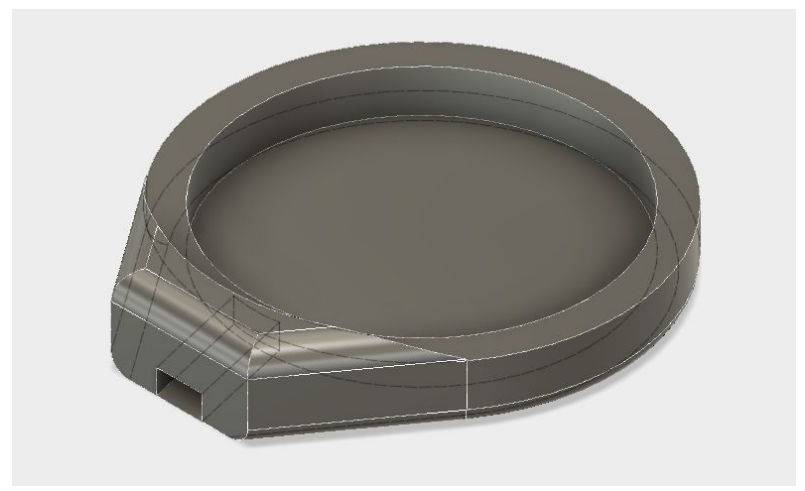

Fig. 2 Piezoelectric capsule designed in CAD.

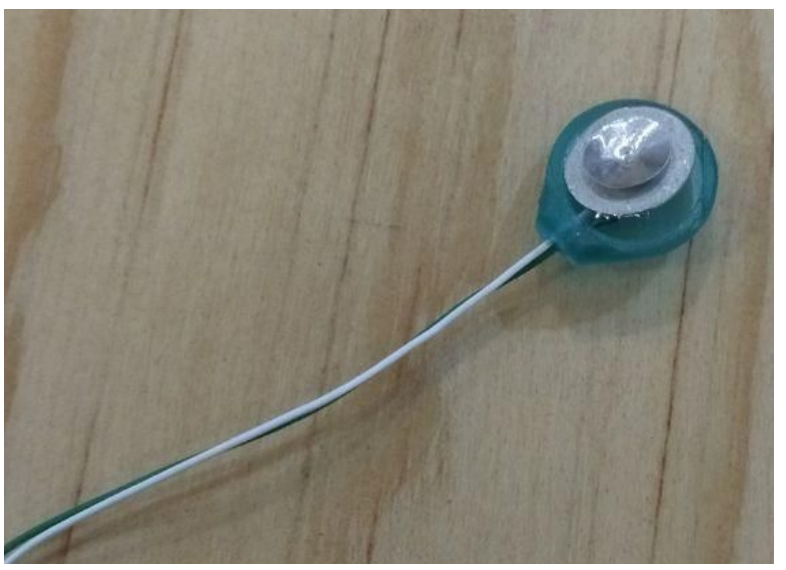

Fig. 3 Capsule with the piezoelectric in place.

We incorporated a display showing the emission elapsed time to verify the functionality of the device, along with a trigger button and a LED, whose intensity is proportional to that of the ultrasound emission.

The driver system used was the Arduino microcontroller (Pro Mini model), along with a $16 \times 2$ blocks LCD, a simple pushbutton switch, a voltage booster, a BJT transistor and the ultrasound detector circuit. The microcontroller produced a 40 $\mathrm{kHz}$ square signal connected to the base of the transistor, which allowed it to power the piezoelectric with $20 \mathrm{~V}$ from the voltage booster. The pushbutton sent a signal to the 
microcontroller when pressed so that the ultrasound emission would start. The screen displayed the elapsed time emitting in seconds and indicated if the device is emitting or in standby.

The sketch for the electronics contemplates the interaction that the user would have with the device: a visible screen, a trigger button with an ultrasonic sensor, a witness LED, and two connection ports, one for the piezoelectric and another to power the device. A USB type B power port was selected, because it is easier to align, can be connected to any power USB port, and is common in printers and medical devices.

The witness LED system was built with a piezoelectric ultrasonic receptor that outputs a voltage signal in the presence of US, with an amplification stage which output is connected to the LED. The witness LED circuit was based on the design of an ultrasonic rangefinder of Wayne Holder [39], published on his internet site. After assembly, the circuit was tested and verified exposing it to ultrasound with an ultrasonic rangefinder, and to ambient noise. The receptor piezoelectric datasheet [40] shows that the piezoelectric is highly sensitive to $40 \mathrm{kHz}$ signals.

According to the setup in [5], the device should work for 5 minutes, a lapse of time that has been tested to be enough to produce observable changes in the bacterial biofilm.

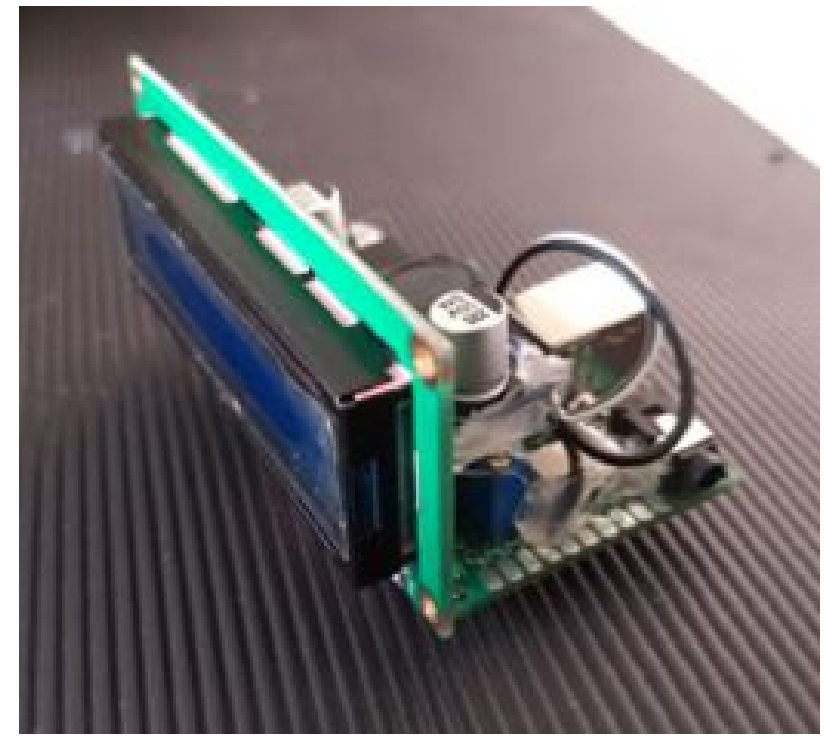

Fig. 4 The driver circuit.

The construction of the case for the circuits was made after assembling the electronics, to be able to measure the finished system. The sketch that served to accommodate the electronic parts included holes for the ports, the button, and the screen. The design was made in CAD software in two sections, as would be a container with a cover that could be then pasted together after having verified that it does emit ultrasound, see Fig. 4 and 5.

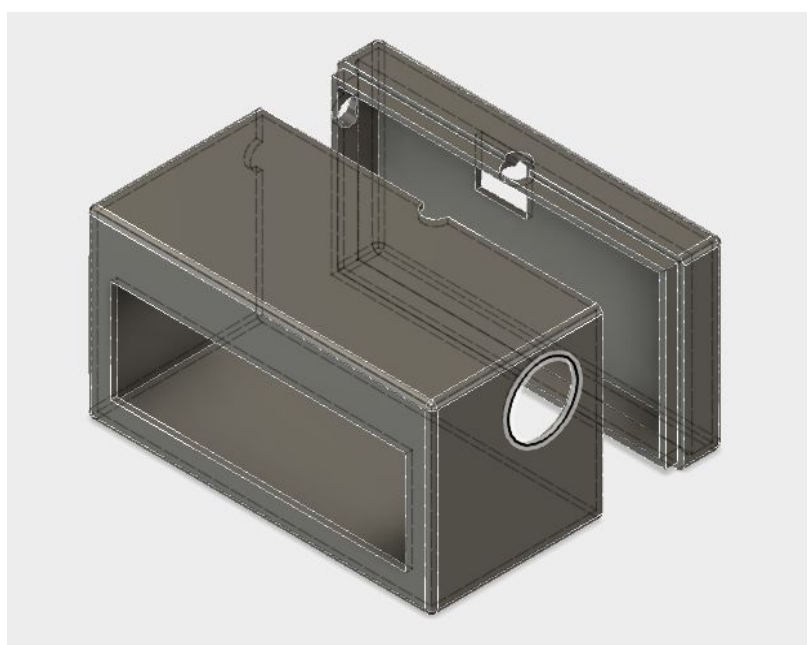

Fig. 5 Driver circuit case designed in CAD.

In Fig. 6 we can observe the final prototype, embedded in a real palatal obturator and ready for its first test. An important consideration during its usage is to add water to the surface of the palatal obturator to increase the cavitation medium.

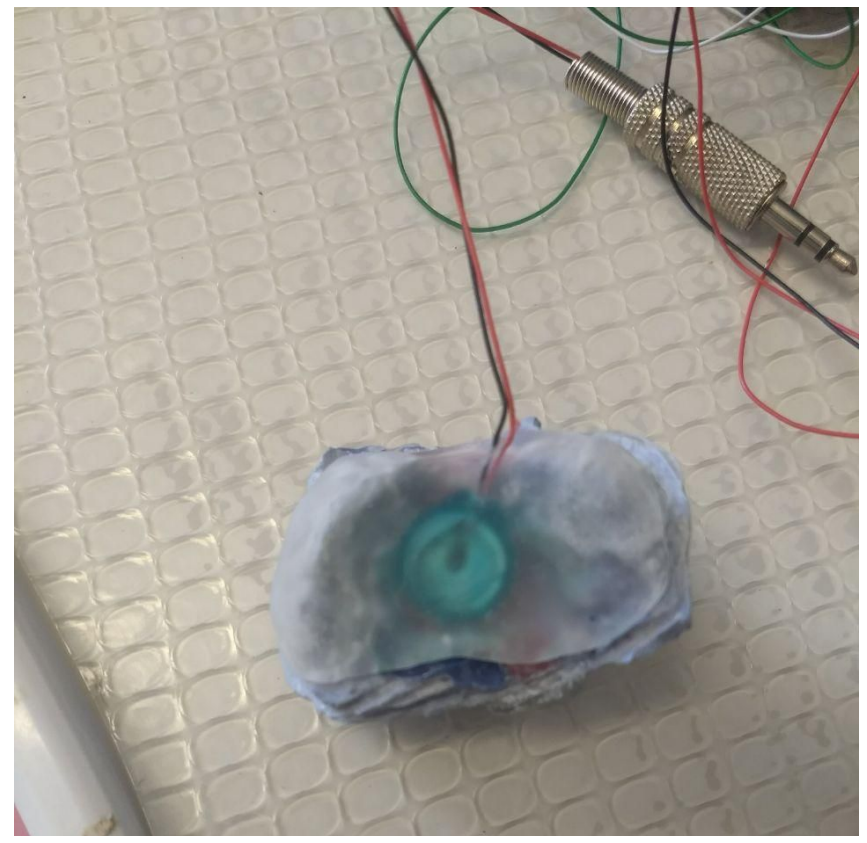

Fig. 6 Capsule embedded an acrylic palatal obturator

We assessed the functionality of the prototype with the witness LED using the resonance conic bell included in the sensor and without that amplifier. The presence of the bell complicates the placement of the membrane in the obturator. Although the ultrasound is attenuated without the amplifier, 
the test demonstrated that without the resonance bell vibration still occurs, so cavitation is still possible.

The power of the US emitted with this prototype is uncertain because the lack of acoustic measurement equipment and to the relatively small amount of power it outputs, that makes a thermal measuring process complicated.

The power of the US emitted with this prototype is uncertain because the lack of acoustic measurement equipment and to the relative small amount of power it outputs, that makes a thermal measuring process complicated. When powering the prototype with a connected multimeter it appeared to consume $4 \mathrm{~mA}$ of current, and given the 20 RMS volts in its electrodes and assuming no energy loss, a maximum of 80 milliwatts of power was emitted along the $0.785 \mathrm{~cm}^{2}$ of the piezoelectric's surface, or $0.1019 \mathrm{~W} / \mathrm{cm}^{2}$.

On the other hand, the capsule assembly is a delicate process because requires high control applying the glue, so a new design of capsule composed of 2 solid parts with the membrane between them has to be tested. This second design must not only maintain the cable duct, but may also extend the duct behind the piezoelectric. In this first prototype, the piezoelectric tended to be tilted because of the cables it has behind, so a new duct will allow it to lay flat.

A precise and accurate processes will be necessary to solder the piezoelectric in a further industrial stage. The electrodes in the piezoelectric showed to be highly sensible to heat. While soldering at $320^{\circ}$ electrodes began to detach, and once a cable has been soldered to it, its manipulation could also detach the electrode.

\section{Conclusions}

This work presented the design and construction of a prototype to kill bacteria in the mouth of patients with cleft palate. The device incorporates a piezoelectric transducer that emitted $40 \mathrm{kHz}$ ultrasound at $110 \mathrm{~dB}$, connected to a driver circuit that generates a $40 \mathrm{kHz}$ square signal from 0 to $20 \mathrm{~V}$. The transducer, protected by a case, is embedded into an acrylic palatal obturator allowing it to emit ultrasound. The proposed device is low-cost and simple to construct.

The functionality of our proposed prototype is satisfactory. The employed materials suits with the quality and sanitation requirements for medical devices.

We adjust the US configuration to inactivate Streptococcus pneumoniae and similar bacteria according to the observations in the state-of-the-art. The next step of this investigation is to assess the potential of the proposed prototype to kill bacteria under a simulated in vitro scenario and then under real-world cases. Further work must be focused on adjusting power, frequency and exposure time.

\section{AcKNowledgments}

Thanks to Belinka González-Fernández, Jezabel Guzman, Moises Jimenez, Karina Machorro and Dianelly Torres for their helpful insights to develop this work.

\section{REFERENCES}

[1] I. T. Micoló, M. E. Guzmán, and L. Figueroa, "Análisis de la incidencia, prevalencia y atención del labio y paladar hendido en México," Cirug\{'|i\}a plástica, vol. 13, no. 1, pp. 35-39, 2003.

[2] C. A. González-Osorio et al., "Estudio ecológico en México (2003-2009) sobre labio y/o paladar hendido y factores sociodemográficos, socioeconómicos y de contaminación asociados," vol. 74, no. 6, pp. 377-387, 2011.

[3] C. for D. Co. and Prevention, "Facts about Cleft Lip and Cleft Palate," June 27, 2017. [Online]. Available: https://www.cdc.gov/ncbddd/birthdefects/cleftlip.html. [Accessed: 01-Mar-2018].

[4] R. S. Dhillon, "The Middle Ear in Cleft Palate Children Pre and Post Palatal Closure," J. R. Soc. Med., vol. 81, no. 12, pp. 710-713, Dec. 1988.

[5] J. F. B. de São José, N. J. de Andrade, A. M. Ramos, M. C. D. Vanetti, P. C. Stringheta, and J. B. P. Chaves, "Decontamination by ultrasound application in fresh fruits and vegetables," Food Control, vol. 45, pp. 36-50, 2014.

[6] F. A Duck, A. C Baker, and H. C Starritt, Ultrasound in Medicine. Great Britain: CRC Press, 1998.

[7] R. Stotzka, J. Wuerfel, T. O. Mueller, and H. Gemmeke, "Medical imaging by ultrasound computer tomography," in Medical Imaging 2002: Ultrasonic Imaging and Signal Processing, 2002, vol. 4687, pp. $110-120$.

[8] M. T. Corbo Rodríguez and M. E. Marimón Torres, "Labio y paladar fisurados: Aspectos generales que se deben conocer en la atención primaria de salud," Rev. Cuba. Med. Gen. Integr., vol. 17, no. 4, pp. 379-385, 2001.

[9] M. del Rosario Gutiérrez-Rodríguez, A. del Carmen

Peregrino-Mendoza, M. E. Borbolla-Sala, and R. M. Bulnes-López, "Beneficios del tratamiento temprano con ortopedia pre-quirúrgica en neonatos con labio y paladar hendido," Salud en Tabasco, vol. 18, no. 3, pp. 96-102, 2012.

[10] J. C. Chang et al., "UV inactivation of pathogenic and indicator microorganisms.," Appl. Environ. Microbiol., vol. 49, no. 6, pp. $1361-1365,1985$.

[11] Z. Herceg, A. R. Jambrak, V. Lelas, and S. M. Thagard, "The effect of high intensity ultrasound treatment on the amount of Staphylococcus aureus and Escherichia coli in milk," Food Technol. Biotechnol., vol. 50, no. 1, p. 46, 2012.

[12] A. Oikarinen, J. Karvonen, J. Uitto, and M. Hannuksela, "Connective tissue alterations in skin exposed to natural and therapeutic UV-radiation.," Photodermatol., vol. 2, no. 1, pp. 15-26, 1985.

[13] C. A. Alonso and R. M. R. Gomes, "Aplicación de ultrasonidos en el dolor cervical de origen inespec \{'li\}fico," Fisioterapia, vol. 29, no. 4, pp. 176-182, 2007.

[14] W. D. O'Brien, "Ultrasound-biophysics mechanisms," Prog. Biophys. Mol. Biol., vol. 93, no. 1-3, pp. 212-255, Jan. 2007.

[15] C. C. Church, E. L. Carstensen, W. L. Nyborg, P. L. Carson, L. A. Frizzell, and M. R. Bailey, "The Risk of Exposure to Diagnostic Ultrasound in Postnatal Subjects," J. Ultrasound Med., vol. 27, no. 4, pp. 565-592, Apr. 2008.

[16] S. Gao, G. D. Lewis, M. Ashokkumar, and Y. Hemar, "Inactivation of microorganisms by low-frequency high-power ultrasound: 1 . Effect of growth phase and capsule properties of the bacteria," Ultrason. Sonochem., vol. 21, no. 1, pp. 446-453, 2014.

16 $^{\text {th }}$ LACCEI International Multi-Conference for Engineering, Education, and Technology: "Innovation in Education and Inclusion", 19-21 July 2018, Lima, Peru. 
[17] K. R. Hardie and K. Heurlier, "Establishing bacterial communities by 'word of mouth': LuxS and autoinducer 2 in biofilm development," Nat. Rev. Microbiol., vol. 6, no. 8, pp. 635-643, Aug. 2008.

[18] G. Scherba, R. M. Weigel, and W. D. O’Brien, "Quantitative assessment of the germicidal efficacy of ultrasonic energy.," Appl. Environ. Microbiol., vol. 57, no. 7, pp. 2079-84, Jul. 1991.

[19] W. G. Pitt, M. O. McBride, J. K. Lunceford, R. J. Roper, and R. D. Sagers, "Ultrasonic enhancement of antibiotic action on gram-negative bacteria.," Antimicrob. Agents Chemother., vol. 38, no. 11, pp. 2577-82, Nov. 1994.

[20] E. Joyce, S. S. Phull, J. P. Lorimer, and T. J. Mason, “The development and evaluation of ultrasound for the treatment of bacterial suspensions. A study of frequency, power and sonication time on cultured Bacillus species," Ultrason. Sonochem., vol. 10, no. 6, pp. 315-318, 2003.

[21] A. M. Rediske, W. C. Hymas, R. Wilkinson, and W. G. Pitt, "Ultrasonic enhancement of antibiotic action on several species of bacteria.," J. Gen. Appl. Microbiol., vol. 44, no. 4, pp. 283-288, Aug. 1998.

[22] R. V. Peterson and W. G. Pitt, "The effect of frequency and power density on the ultrasonically-enhanced killing of biofilm-sequestered Escherichia coli," Colloids Surfaces B Biointerfaces, vol. 17, no. 4, pp. 219-227, Apr. 2000.

[23] W. G. Pitt and S. A. Ross, "Ultrasound Increases the Rate of Bacterial Cell Growth," Biotechnol. Prog., vol. 19, no. 3, pp. 1038-1044, Jun. 2003.

[24] J. C. Carmen et al., "Treatment of biofilm infections on implants with low-frequency ultrasound and antibiotics.," Am. J. Infect. Control, vol. 33, no. 2, pp. 78-82, Mar. 2005.

[25] T. Flynn, C. Möller, R. Jönsson, and A. Lohmander, "The high prevalence of otitis media with effusion in children with cleft lip and palate as compared to children without clefts," Int. J. Pediatr. Otorhinolaryngol., vol. 73, no. 10, pp. 1441-1446, 2009.

[26] J. F. Stanievich, C. D. Bluestone, J. A. Lima, R. H. Michaels, D. Rohn, and M. Z. Effron, "Microbiology of chronic and recurrent otitis media with effusion in young infants," Int. J. Pediatr. Otorhinolaryngol., vol. 3, no. 2, pp. 137-143, Apr. 1981.

[27] P. Sheahan, I. Miller, J. N. Sheahan, M. J. Earley, and A. W. Blayney, "Incidence and outcome of middle ear disease in cleft lip and/or cleft palate," Int. J. Pediatr. Otorhinolaryngol., vol. 67, no. 7, pp. 785-793, Jul. 2003.

[28] K. Ryan, C. G. Ray, N. Ahmad, W. L. Drew, and J. Plorde, Sherris Medical Microbiology, 4th Edition. United States of America: McGraw-Hill, 2004.

[29] A. Carola, M. Ayala, D. Edith, and S. Vergara, "Factores de riesgo materno predominantes asociados con labio leporino y paladar hendido en los recién nacidos."

[30] V. Preado J., "Conceptos microbiológicos de Streptococcus pneumoniae: BASIC MICROBIOLOGICAL ASPECTS," Rev. Chil. infectología, vol. 18, pp. 6-9, 2001.

[31] S. Gao, G. D. Lewis, M. Ashokkumar, and Y. Hemar, "Inactivation of microorganisms by low-frequency high-power ultrasound: 2. A simple model for the inactivation mechanism," Ultrason. Sonochem., vol. 21, no. 1, pp. 454-460, 2014.

[32] K. Todar, "Streptococcus pneumoniae and pneumococcal pneumonia," textbookbacteriology.net, 2012. [Online]. Available: http://textbookofbacteriology.net/S.pneumoniae.html. [Accessed: 23-Apr-2018].

[33] O. Linderkamp, P. Y. K. Wu, and H. J. Me1selmanrz6, "Geometry of Neonatal and Adult Red Blood Cells," Pediatr. Res, vol. 17, pp. 250-253, 1983.

[34] A. M. Rediske, N. Rapoport, and W. G. Pitt, "Reducing bacterial resistance to antibiotics with ultrasound," Lett. Appl. Microbiol., vol. 28, no. 1, pp. 81-84, 1999.

[35] R. H. Musgrave and J. Bremner, "COMPLICATIONS OF CLEFT
PALATE SURGERY," Plast. Reconstr. Surg., vol. 26, no. 2, p. 180, 1960.

[36] A. Rennie, L. J. Treharne, and B. Richard, "Throat Swabs Taken on the Operating Table Prior to Cleft Palate Repair and Their Relevance to Outcome: A Prospective Study," Cleft Palate-Craniofacial J., vol. 46, no. 3, pp. 275-279, May 2009.

[37] D. Bogaert et al., "Colonisation by Streptococcus pneumoniae and Staphylococcus aureus in healthy children," Lancet, vol. 363, no. 9424, pp. 1871-1872, Jun. 2004.

[38] E. M. Arief, Z. Mohamed, and F. M. Idris, "Study of Viridans Streptococci and Staphylococcus Species in Cleft Lip and Palate Patients Before and After Surgery," Cleft Palate-Craniofacial J., vol. 42, no. 3, pp. 277-279, May 2005.

[39] W. Holder, "DIY Ultrasonic Rangefinder - Wayne's Tinkering Page," 2014. [Online]. Available:

https://sites.google.com/site/wayneholder/ultrasonic-rangefinder. [Accessed: 30-Apr-2018].

[40] RS Components, "Ultrasonic transducers." 1997.

$1^{\text {th }}$ LACCEI International Multi-Conference for Engineering, Education, and Technology: "Innovation in Education and Inclusion”, 19-21 July 2018, Lima, Peru. 